\title{
MASH BEAN [Vigna mungo (L.) HEPPER] GERMPLASM EVALUATION AT DIFFERENT ECOLOGICAL CONDITIONS OF PAKISTAN
}

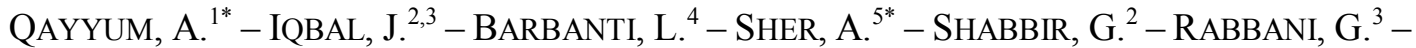 \\ RAFIQ, M. K. ${ }^{6}-$ TAREEN, M. N. $^{7}$ - TAREEN, M. J. ${ }^{7}-$ AMIN, B. A. Z. ${ }^{8}$ \\ ${ }^{1}$ Department of Agronomy, The University of Haripur, 22620, Pakistan \\ ${ }^{2}$ Department of Plant Breeding and Genetics, Pir Mehr Ali Shah-Arid Agriculture University \\ Rawalpindi, 46300, Pakistan
}

${ }^{3}$ Pulses Program, Barani Agriculture Research Institute, Chakwal, 48800, Pakistan

${ }^{4}$ Department of Agricultural and Food Sciences, University of Bologna, 40127, Italy

${ }^{5}$ College of Agriculture, Bahauddin Zakariya University, Bahadur Campus Layyah, 31200, Pakistan

${ }^{6}$ School of Geosciences, The University of Edinburgh, EH3 9FF, United Kingdom

${ }^{7}$ Agriculture Research Institute, Sariab, Quetta, Pakistan

${ }^{8}$ Department of Environmental Sciences, COMSATS University Islamabad, Abbottabad Campus, 22060, Pakistan

${ }^{*}$ Corresponding authors

e-mail:aqayyum@uoh.edu.pk;ahmad.sher@bzu.edu.pk

(Received $1^{\text {st }}$ Feb 2019; accepted $8^{\text {th }}$ Mar 2019)

\begin{abstract}
Mash bean [Vigna mungo (L.) Hepper], is the third largest pulse crop in Pakistan. Nine advanced breeding lines were compared with two commercial varieties, in order to investigate their potential prior to release as cultivated varieties. A field experiment was conducted in three environments in Punjab, Pakistan, during the 2014 kharif (wet) season. Developmental, morphological and yield traits included time to reach $90 \%$ maturity, plant height, the number of branches, grain yield (GY) and its components. GY varied between $778 \mathrm{~kg} \mathrm{ha}^{-1}$ (cv. Mash Arooj) and $1005 \mathrm{~kg} \mathrm{ha}^{-1}$ (line 11CM-709) in the eleven genotypes, and between 438 and $1667 \mathrm{~kg} \mathrm{ha}^{-1}$ in the three environments. The lowland environment (Piplan) was the highest yielding, despite significant water deficit. In each genotype average yield across the three environments, plotted against the regression slope of specific yield vs. average yield in each environment, allowed yield potential and stability to be shown. As a result, five breeding lines exhibited a remarkable yield potential in exchange for low stability, i.e. modest suitability for low yielding environments. The remaining lines yielded as the two commercial varieties with a higher stability across environments. These are good premises for mash bean wider diffusion in the surveyed area.
\end{abstract}

Keywords: mash bean, black gram, genotypes, plant traits, yield potential, yield stability

\section{Introduction}

Mash bean [Vigna mungo (L.) Hepper], black gram, is an important legume crop widely grown in Asia and has great value as food, fodder and green manure. In addition to improving the soil fertility, it is a cheap source of protein for direct human consumption. It has a close relationship with human being due to high and easily digestible protein content $(20.8-30.5 \%)$ and carbohydrate $(56.5-63.7 \%)$ on dry weight 
basis (Sharma et al., 2012). Thus, it has a great potential to improve protein deficiency in human beings by providing a low cost protein. Mash bean not only fixes free atmospheric $\mathrm{N}_{2}$, but also enriches the soil with nitrogen for the growth of succeeding crops (Sen, 1996). This crop can be successfully grown on marginal lands where other crops perform poorly (Ghafoor et al., 2003).

By establishing the International Year of Pulses in 2016, the FAO has shown renewed interest in these crops as components of the diets in many countries (Sharma, 2014). This is supported by their annual increase rate that, based on the cited source, has resulted slightly higher than that of cereals (1.84\% vs. $1.82 \%$ over the past two decades).

Despite these premises, worldwide yield of mash bean including Pakistan is very poor. In Pakistan it is the least researched crop among pulses despite its high nutritive and economic value, due to which its area of cultivation and production have both gradually decreased. In Pakistan during 2016-17, mash bean was grown over an area of 17 thousand hectares with a total production of 7 thousand tonnes. However, it is estimated that mash bean is the major food legume grown in Pakistan during the summer season after gram and mung bean: it occupies $1.5 \%$ of total pulses area contributing $1.4 \%$ to total pulses production (GOP, 2017). Though it is grown all over the country, Punjab is the major mash bean producing province. The productivity of mash bean in the country has remained quite low as compared to other grain legumes (GOP, 2017).

Mash bean is mainly grown as a pulse crop, although sometimes it is used as a green manure to improve soil fertility. Mash bean is a short-duration crop that requires less water as compared to other summer crops and thus qualifies as a suitable candidate for rainfed areas. Successful cultivation in rainfed areas can give significant economic benefits to farmers (Singh et al., 2015). Like other legumes, mash bean also possesses the ability to establish a symbiotic relationship with the nitrogen fixing soil bacteria generally known as "rhizobia", which is a term used for a broad range of microsymbionts from $\alpha$ and $\beta$-Proteobacteria that establish symbiosis with leguminous plants for biological nitrogen fixation. Mash bean can fix approximately $37-83 \mathrm{~kg} \mathrm{ha}^{-1}$ of nitrogen through this symbiotic association (Mohammad et al., 2010).

The performance of any character is a combined result of the genotype, the environment and the interaction between genotype $(\mathrm{G})$ and environment (E). It is necessary to research on yield stability and $G \times E$ interactions to improve consistency in performance across diverse environments and years (Blanche et al., 2009). Significant genotype and environment interactions occur when the responses of two genotypes to different levels of environmental stress are variable. An efficient genotype must remain consistent in different years and environmental conditions (Hill, 1975). Better understanding of the $\mathrm{G} \times \mathrm{E}$ interactions and stability in crops is generally used as a decision tool, particularly at the final stage of variety development process, to generate essential information on pattern of adaptation in breeding lines, screen new varieties for release, and determine the recommendation domains for released varieties (Yan and Kang, 2003).

Based on these premises, the main objectives of the present study were to identify more high-yielding, stable and promising lines and areas where mash bean lines would be adapted. The novelty of this research is that promising lines, having desirable plant traits and high yield stability, could be introduced as released varieties. 


\section{Material and Methods}

\section{Plant materials, environments and experimental conditions}

Mash bean germplasm comprising nine advanced breeding lines (11CM-707, 11CM-705, 11CM-709, 11CM-701, 11CM-703, 11CM-706, 11CM-710, 11CM-702, $11 \mathrm{CM}-704$ ) and two commercial varieties commonly cultivated among farmers (Chakwal Mash and Mash Arooj) was evaluated over three environments in the framework of Barani Agricultural Research Stations: Chakwal (32 55'49"N 72 51'20"E, $525 \mathrm{~m}$ asl), Piplan (32 $17^{\prime} 12^{\prime \prime N} 71^{\circ} 21^{\prime} 59 \mathrm{E}, 198 \mathrm{~m}$ asl) and Fateh Jang (33 $33^{\circ} 57^{\prime \prime N} 72^{\circ} 38^{\prime} 57^{\prime \prime E}, 514$ $\mathrm{m}$ asl) in Punjab province, Pakistan, during 2014 (Figure 1).

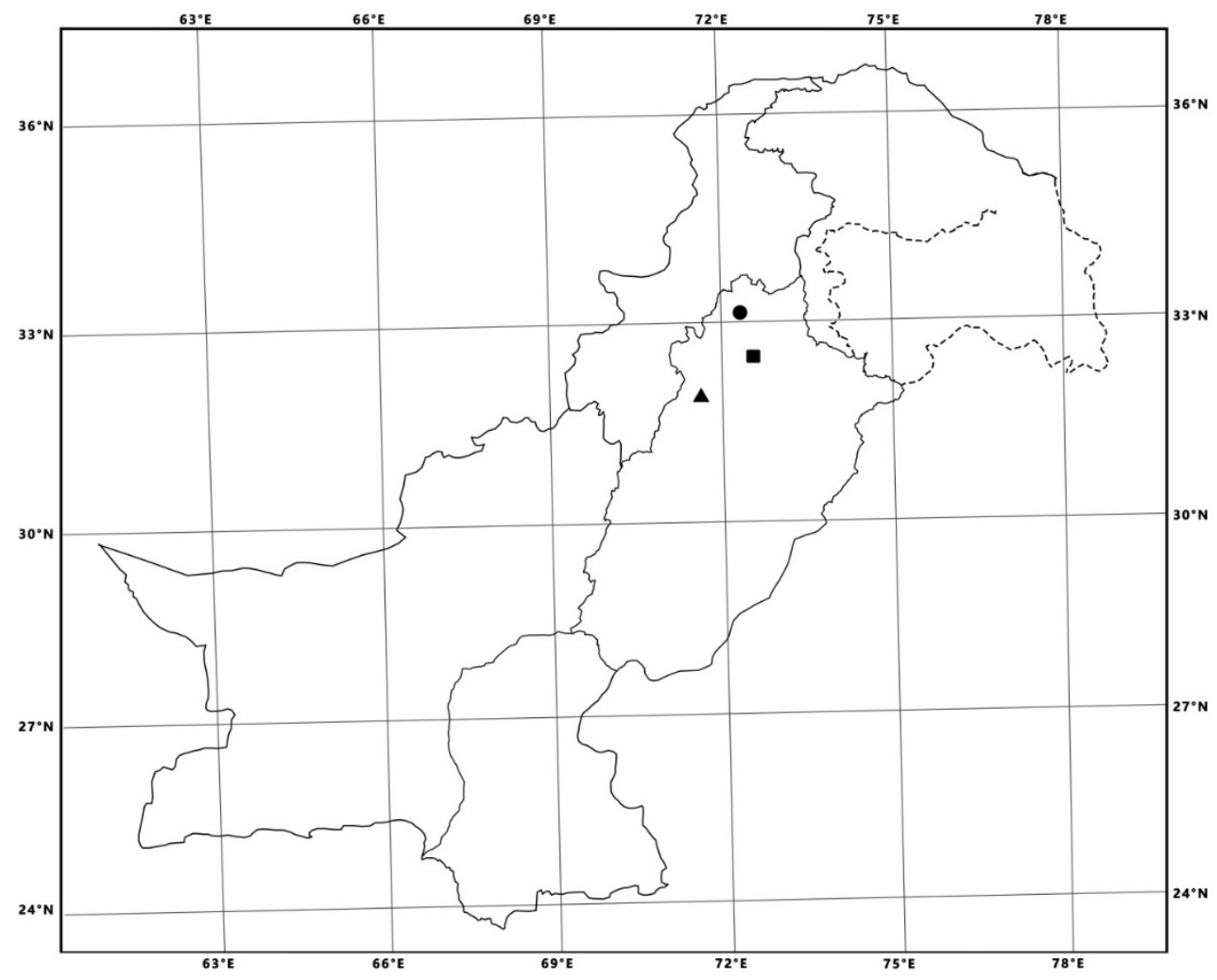

Figure 1. Mash bean germplasm evaluation at Barani Agricultural Research Stations: Chakwal

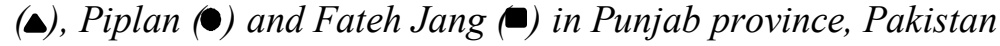

The experiment was laid out in a Randomized Complete Block Design (RCBD) at three replicates, with a net plot size of $4.8 \mathrm{~m}^{2}(4 \times 1.2 \mathrm{~m})$. Preceding crop, in the frame of the National Coordinated Pulses Program, was groundnut at all three environments. The fields were supplied with a recommended dose of Di-Ammonium Phosphate (DAP) fertilizer $\left(50 \mathrm{~kg} \mathrm{ha}^{-1}\right)$ before preparation of seed bed. Seeds of mash bean were sown with hand drill and planted at a depth of 3-4 cm. Row width was $30 \mathrm{~cm}$, while plant to plant distance was kept at $10 \mathrm{~cm}$ by means of over-seeding and subsequent thinning of seedlings. The crop was sown on July 22 and harvested on October 10, 2014, at all three environments. Hand weeding was carried out, and all recommended cultural practices were followed to maintain a healthy crop stand. Irrigation was not applied.

Weather during the experiment (minimum and maximum temperature, precipitation and relative humidity) was daily monitored at the three environments' meteorological 
stations. Based on this, reference evapo-traspiration $\left(\mathrm{ET}_{0}\right)$ was calculated with the Hargreaves equation (Hargreaves and Samani, 1985). The thermal sum of average daily temperatures above $10^{\circ} \mathrm{C}$ was also calculated, and expressed as growing degree days (GDD) from sowing to harvest. GDD are a measure of heat accumulation commonly used to predict plant development, and rate genotype behaviour across time and space.

\section{Crop monitoring}

The following traits pertaining to plant development and morphology were specifically monitored during the experiment: seedling emergence, days to reach the beginning of the reproductive stage (50\% flowering) and final senescence (90\% maturity), plant height and the number of primary branches.

At maturity, five plants from each plot were randomly selected and the number of pods per plant and seeds per pod were counted. The grain was then harvested from the whole plot surface $\left(4.8 \mathrm{~m}^{2}\right)$, weighted, and a sample was oven dried $\left(48\right.$ hours at $\left.105^{\circ} \mathrm{C}\right)$. Based on this, grain yield per hectare adjusted at $12 \%$ moisture was determined. Finally, the thousand-seed weight that is the third yield component was determined, based on pods per plant and seeds per pod that are the other two yield components, and grain yield.

\section{Data analysis}

Morphological, developmental and yield data were submitted to a combined ANOVA for the sources Genotypes $(G)$, Environments $(E)$, and their interaction $(G \times E)$, using Rprogram 3.2.1 (R Development Core Team 2012). Student Newman-Keuls (SNK) test at $P \leq 0.05$ was used to separate data of significant ANOVA sources.

Pearson's correlation (r) between crop traits was assessed to evaluate the degree of inter-relationship. Additionally, the relative importance of yield components on grain yield was assessed through the Lindeman, Merenda and Gold's (LMG) method (Lindeman et al., 1980).

Lastly, yield data representation according to Eberhart and Russel (1966) was used to highlight each genotype's average yield vs. yield stability among experimental environments.

\section{Results}

\section{Meteorological conditions}

The experiment was conducted during the kharif (wet) season in 2014. The amount of precipitation greatly differed among the three environments: 390, 169 and $852 \mathrm{~mm}$ were received during mash bean cultivation in Chakwal, Piplan and Fateh Jang, respectively. Differences were also shown in average temperature: $27.4,31.5$ and $28.2^{\circ} \mathrm{C}$ at the three respective environments. Thus, Piplan that has a lower elevation appeared a drier and warmer environment than Chakwal and Fateh Jang. The thermal sum cumulated steadily from sowing to harvest in all environments (Figure 2). However, Piplan diverged from the other two environments, achieving a final 1744 GDD vs. an average 1444 GDD of the combined Chakwal and Fateh Jang.

The balance between water supply (precipitation) and demand $\left(\mathrm{ET}_{0}\right)$ showed very different patterns (Figure 2). Chakwal remained slightly above the break-even line for most of the time. Piplan portrayed increasing water deficit up to $-264 \mathrm{~mm}$ at harvest. 
Lastly, Fateh Jang featured much more $\mathrm{P}$ than $\mathrm{ET}_{0}$, resulting in a considerable gain $(+477$ $\mathrm{mm})$.

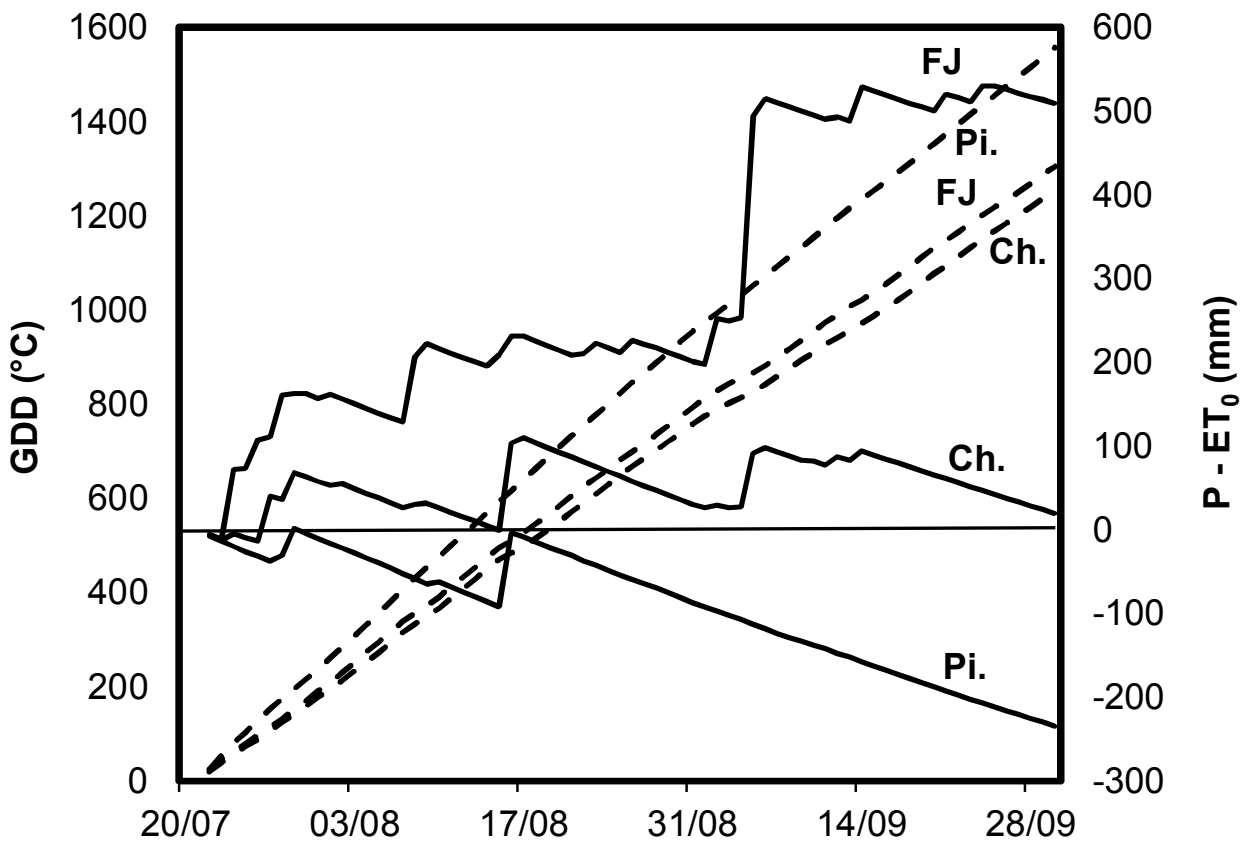

Figure 2. Cumulated growth degreee days (GDD) (dashed lines) and precipitation minus reference evapo-traspiration ( $\left.P-E T_{0}\right)$ (solid lines) from seeding to harvesting in the three environments. Ch., Chakwal; Pi., Piplan; FJ, Fateh Jang. The horizontal line indicates the break-even in the balance between precipitation and evapotranspiration

\section{Plant development and morphology}

Seedling emergence was very high (average, 92.6\%); no ANOVA source (G, E, G × E) significantly influenced this trait (Table 1). The eleven genotypes exhibited a modest difference in earliness at 50\% flowering (Table 1): only 11CM-703 was significantly earlier that the rest of genotypes by an approximate six days. An average 48 days was needed to achieve 50\% flowering in the three environments, corresponding to 969 GDD.

A stronger differentiation was shown at 90\% maturity (Table 1): 11CM-704 was the earliest genotype at par with 11CM-707, 11CM-703 and 11CM-710. 11CM-706 and $11 \mathrm{CM}-702$ were the latest, and the other five genotypes were statistically undifferentiated between the two groups. Slight differences to achieve $90 \%$ maturity were also shown among the three environments. An average 78 days was needed, corresponding to 1515 GDD.

Plant height varied between 37.9 and $44.4 \mathrm{~cm}$ among the eleven genotypes (Table 1): 11CM-701, 11CM-702 and Mash Arooj were the shortest genotypes; Chakwal Mash was the tallest, while the other seven genotypes were intermediate. Among the three environments, Piplan featured much taller plants (average, $+35 \%$ ) than Chakwal and Fateh Jang.

In contrast to this, the number of primary branches was undifferentiated (Table 1). An average 1.88 branches per plant was recorded, with minor differences among genotypes and environments. 
Table 1. Plant development and morphology of eleven genotypes grown at the three environments

\begin{tabular}{|c|c|c|c|c|c|}
\hline Source & $\begin{array}{c}\text { Seedling emergence } \\
(\%)\end{array}$ & $\begin{array}{l}\text { Days to } 50 \% \\
\text { flowering }\end{array}$ & $\begin{array}{l}\text { Days to } 90 \% \\
\text { maturity }\end{array}$ & $\begin{array}{l}\text { Plant height } \\
\text { (cm) }\end{array}$ & $\begin{array}{l}\text { Primary } \\
\text { branches }\end{array}$ \\
\hline \multicolumn{6}{|l|}{ Genotypes (G) } \\
\hline $11 \mathrm{CM}-707$ & 93.1 & $48.9 \mathrm{a}$ & $78.0 \mathrm{~b}$ & $40.7 \mathrm{ab}$ & 1.86 \\
\hline $11 \mathrm{CM}-705$ & 92.7 & $49.1 \mathrm{a}$ & $78.5 \mathrm{ab}$ & $40.7 \mathrm{ab}$ & 1.91 \\
\hline 11CM-709 & 92.5 & $50.9 \mathrm{a}$ & $78.3 \mathrm{ab}$ & $40.5 \mathrm{ab}$ & 1.86 \\
\hline $11 \mathrm{CM}-701$ & 92.1 & $46.6 \mathrm{a}$ & $78.7 \mathrm{ab}$ & $38.9 \mathrm{~b}$ & 1.86 \\
\hline $11 \mathrm{CM}-703$ & 92.4 & $43.0 \mathrm{~b}$ & $78.0 \mathrm{~b}$ & $40.0 \mathrm{ab}$ & 1.97 \\
\hline $11 \mathrm{CM}-706$ & 92.2 & $48.1 \mathrm{a}$ & $79.2 \mathrm{a}$ & $39.7 \mathrm{ab}$ & 1.84 \\
\hline $11 \mathrm{CM}-710$ & 92.3 & $50.1 \mathrm{a}$ & $78.0 \mathrm{~b}$ & $40.5 \mathrm{ab}$ & 1.82 \\
\hline $11 \mathrm{CM}-702$ & 93.2 & $48.2 \mathrm{a}$ & $79.3 \mathrm{a}$ & $39.1 \mathrm{~b}$ & 1.88 \\
\hline $11 \mathrm{CM}-704$ & 92.7 & $49.4 \mathrm{a}$ & $77.9 \mathrm{~b}$ & $40.2 \mathrm{ab}$ & 1.86 \\
\hline Chakwal Mash & 92.7 & $47.0 \mathrm{a}$ & $79.0 \mathrm{ab}$ & $44.4 \mathrm{a}$ & 1.93 \\
\hline Mash Arooj & 92.9 & $47.2 \mathrm{a}$ & $78.3 \mathrm{ab}$ & $37.9 \mathrm{~b}$ & 1.86 \\
\hline$P$ & $0.9554 \mathrm{~ns}$ & $0.0001 * *$ & $0.0465^{*}$ & $0.0304 *$ & $0.9828 \mathrm{~ns}$ \\
\hline \multicolumn{6}{|l|}{ Environments (E) } \\
\hline Chakwal & 92.6 & 47.4 & $78.0 \mathrm{~b}$ & $35.7 \mathrm{~b}$ & 1.83 \\
\hline Piplan & 92.6 & 48.1 & $77.7 \mathrm{~b}$ & $48.6 \mathrm{a}$ & 1.95 \\
\hline Fateh Jang & 92.5 & 48.6 & $79.7 \mathrm{a}$ & $36.4 \mathrm{~b}$ & 1.86 \\
\hline$P$ & $0.9451 \mathrm{~ns}$ & $0.2251 \mathrm{~ns}$ & $0.0001 * *$ & $0.0001 * *$ & $0.1272 \mathrm{~ns}$ \\
\hline \multicolumn{6}{|l|}{$\mathbf{G} \times \mathbf{E}$} \\
\hline$P$ & $0.8308 \mathrm{~ns}$ & $0.1365 \mathrm{~ns}$ & $0.0016^{* *}$ & $0.0054 * *$ & $0.7745 \mathrm{~ns}$ \\
\hline C.V. (\%) & 1.8 & 5.7 & 1.4 & 8.2 & 13.0 \\
\hline
\end{tabular}

ns, * and ** mean non-significant, significant at $P \leq 0.05$ and $P \leq 0.01$, respectively. Different letters indicate statistical differences at $P \leq 0.05$ (SNK test)

\section{Yield and yield components}

The number of pods per plant varied in genotypes between 17.1 (Mash Arooj) and 21.8 (average of 11CM-707, 11CM-705, 11CM-709, 11CM-701, 11CM-703, 11CM-706 and Chakwal Mash) (Table 2). The remaining three genotypes were intermediate (average, 19.0). The three environments exhibited a much higher variation in this trait: Piplan exhibited a more than double data (32.1) than the combined Chakwal and Fateh Jang (average, 14.9).

Compared to this, the number of seeds per pod did not significantly vary among genotypes, whereas modest but significant differences were shown among environments (Table 2): also in this case Piplan displayed a certain advantage over Chakwal and Fateh Jang.

The thousand-seed weight varied among genotypes from a minimum of $17.6 \mathrm{~g}$ (11CM$705)$ to a maximum of $22.5 \mathrm{~g}$ (11CM-703), although ANOVA was significant only at $P$ $<0.10$ (Table 2). Stronger differences were evidenced among the three environments: Piplan exhibited a ca. $40 \%$ higher data than Fateh Jang, which in turn passed Chakwal by ca. $20 \%$.

Grain yield significantly varied among genotypes (Table 2). It ranged from less than $800 \mathrm{~kg} \mathrm{ha}^{-1}$ (Mash Arooj) to more than $1000 \mathrm{~kg} \mathrm{ha}^{-1}$ (11CM-709). The remaining genotypes were quite evenly distributed in this range. Much stronger differences were shown among environments: Chakwal and Fateh Jang averaged $485 \mathrm{~kg} \mathrm{ha}^{-1}$, whereas Piplan achieved ca. 3.5 times as much. 
The significant $\mathrm{G} \times \mathrm{E}$ interaction (Table 2) suggests a different behaviour of the eleven genotypes in the three environments, despite analogous grain yield variation in the single environments (C.V. between $13.9 \%$ and $16.4 \%$; not shown).

Table 2. Grain yield and yield components of eleven genotypes grown at the three environments

\begin{tabular}{|c|c|c|c|c|}
\hline Source & Pods per plant & Seeds per pod & $\begin{array}{l}\text { Thousand seed } \\
\text { weight (g) }\end{array}$ & $\begin{array}{l}\text { Grain yield } \\
\left(\mathrm{kg} \mathrm{ha}^{-1}\right)\end{array}$ \\
\hline \multicolumn{5}{|l|}{ Genotypes (G) } \\
\hline $11 \mathrm{CM}-707$ & $21.5 \mathrm{a}$ & 6.31 & 20.2 & $826 \mathrm{~cd}$ \\
\hline $11 \mathrm{CM}-705$ & $22.0 \mathrm{a}$ & 6.44 & 17.6 & $801 \mathrm{~d}$ \\
\hline 11CM-709 & $22.8 \mathrm{a}$ & 6.37 & 20.5 & $1005 \mathrm{a}$ \\
\hline $11 \mathrm{CM}-701$ & $22.1 \mathrm{a}$ & 6.37 & 20.1 & $944 \mathrm{ab}$ \\
\hline $11 \mathrm{CM}-703$ & $21.2 \mathrm{a}$ & 6.31 & 22.5 & $954 \mathrm{ab}$ \\
\hline $11 \mathrm{CM}-706$ & $21.5 \mathrm{a}$ & 6.40 & 19.7 & $921 \mathrm{abc}$ \\
\hline $11 \mathrm{CM}-710$ & $19.0 \mathrm{ab}$ & 6.44 & 21.5 & $921 \mathrm{abc}$ \\
\hline $11 \mathrm{CM}-702$ & $18.7 \mathrm{ab}$ & 6.37 & 21.7 & $873 \mathrm{bcd}$ \\
\hline $11 \mathrm{CM}-704$ & $19.3 \mathrm{ab}$ & 6.40 & 20.2 & $831 \mathrm{~cd}$ \\
\hline Chakwal Mash & $21.6 \mathrm{a}$ & 6.42 & 18.1 & $817 \mathrm{~cd}$ \\
\hline Mash Arooj & $17.1 \mathrm{~b}$ & 6.40 & 21.7 & $778 \mathrm{~d}$ \\
\hline$P$ & $0.0006^{* *}$ & $0.7684 \mathrm{~ns}$ & $0.0676 \mathrm{~ns}$ & $0.0001 * *$ \\
\hline \multicolumn{5}{|l|}{ Environments (E) } \\
\hline Chakwal & $15.0 \mathrm{~b}$ & $6.35 \mathrm{~b}$ & $15.6 \mathrm{c}$ & $438 \mathrm{c}$ \\
\hline Piplan & $32.1 \mathrm{a}$ & $6.46 \mathrm{a}$ & $26.6 \mathrm{a}$ & $1667 a$ \\
\hline Fateh Jang & $14.8 \mathrm{~b}$ & $6.35 \mathrm{~b}$ & $18.8 \mathrm{~b}$ & $532 \mathrm{~b}$ \\
\hline$P$ & $0.0001 * *$ & $0.0127 *$ & $0.0001 * *$ & $0.0001 * *$ \\
\hline \multicolumn{5}{|l|}{$\mathbf{G} \times \mathbf{E}$} \\
\hline$P$ & $0.0008 * *$ & $0.7012 \mathrm{~ns}$ & $0.0001 * *$ & $0.0001 * *$ \\
\hline C.V. $(\%)$ & 13.6 & 2.6 & 16.3 & 9.3 \\
\hline
\end{tabular}

ns, * and ** mean non-significant, significant at $P \leq 0.05$ and $P \leq 0.01$, respectively. Different letters indicate statistical differences at $P \leq 0.05$ (SNK test)

Data representation according to Eberhart and Russel (1966) allows these differences to be interpreted based on the two factors average yield in the three environments, and regression slope of genotype yield vs. average yield in each environment (Figure 3). In practice, almost all genotypes fall in the first and the third quadrant, i.e. all genotypes belong to either high producing under favourable conditions types (first quadrant), or low producing but suited for unfavourable conditions types (third quadrant).

However, in the former group 11CM-703 could be seen a better genotype than 11CM709 despite lower average yield, thanks to a higher suitability for unfavourable conditions (regression slope closer to 1). In fact, 11CM-703 attained a relative yield $>100.0$ in all three environments, whereas 11CM-709 attained a relative yield $>100.0$ only in two environments (data not shown).

At the opposite end, 11CM-705 and Mash Arooj appeared to be intrinsically suited for unfavourable conditions (regression slope below 0.9), but did not achieve a relative yield $>100.0$ in any of the three environments. Compared to them, 11CM-707 had a similar regression slope, i.e. good suitability for unfavourable conditions, but achieved a relative yield $>100.0$ in the two low yielding environments (Chakwal and Fateh Jang) (data not shown). 


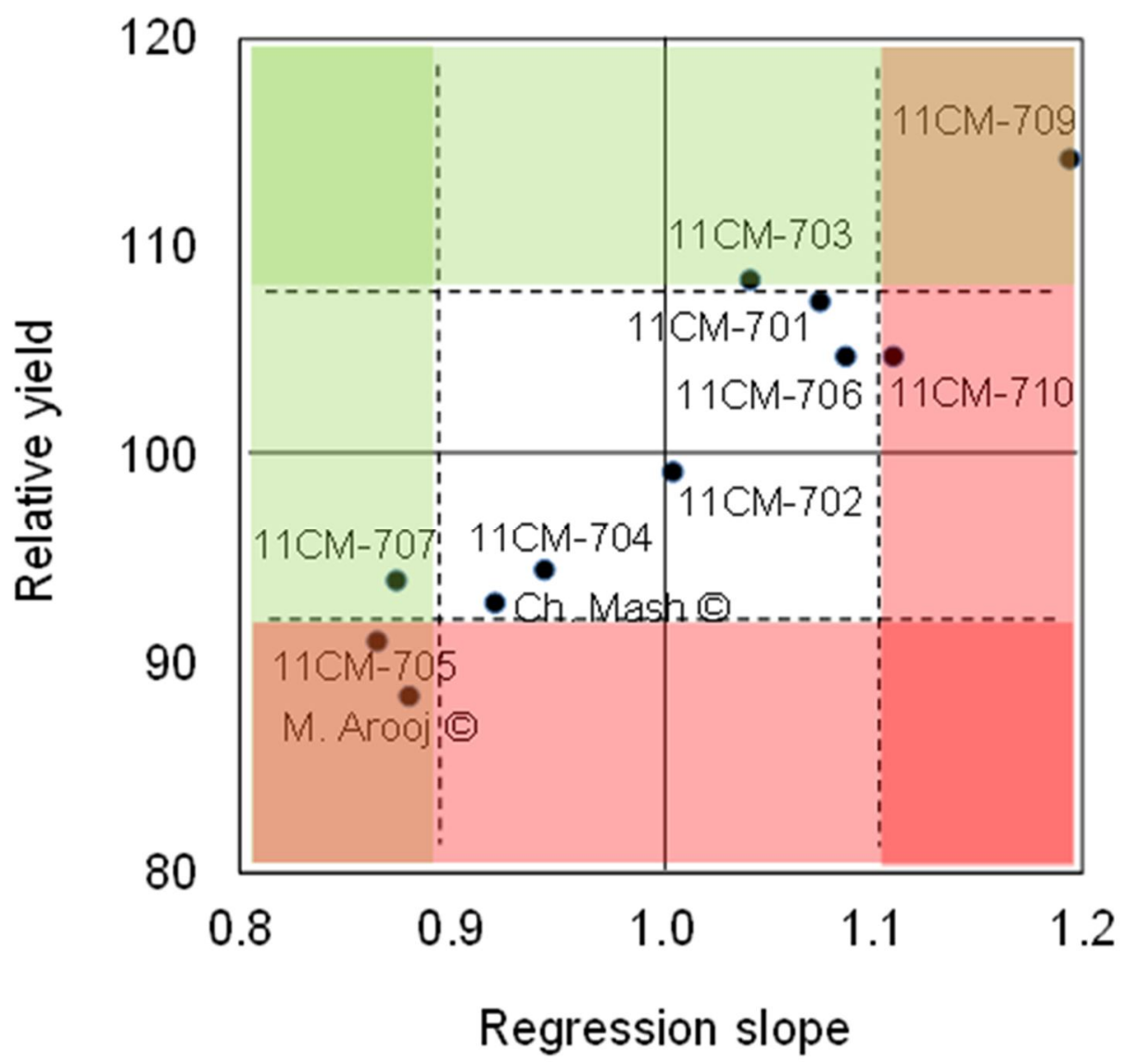

Figure 3. Slope of the regression between genotype yield and average yield in the three environments $(1=$ average $)$, and relative yield across the three environments $(100=$ average $)$. Vertical and horizontal dashed lines indicate \pm standard deviation for the two respective traits. Beyond dashed lines, green and red colour indicate favourable and unfavourable conditions, respectively. Based on this, the four quadrants indicate high yield and low stability (top right); low yield and stability (bottom right); low yield and high stability (bottom left); high yield and stability (top left)

\section{Relationships among developmental, morphological and yield traits}

The table of correlations involving all investigated traits displays several interrelations (Table 3). Seedling emergence was not related to any other trait, which is consistent with the low variation observed for this trait (Table 1). The time to 50\% flowering was not related to any other trait, either, whereas the time to $90 \%$ maturity was adversely related to plant height, the number of pods per plant and final yield. Plant height was directly related to the number of primary branches, the three yield components and, especially $\left(\mathrm{r}=0.86^{* *}\right)$, final yield.

The three yield components were generally inter-related, and unsurprisingly well related to yield. However, the relative importance of yield components through the LMG method (Figure 4) indicated pods per plant and thousand-seed weight as prominent components (respective weights, $49 \%$ and $39 \%$ ), compared to seeds per pod weighing a residual $12 \%$. This is consistent with the different influence exerted by the investigated factors on the three yield components (Table 2). 
Table 3. Pearson's correlations between developmental, morphological and yield traits

\begin{tabular}{c|cccccccc}
\hline & Emergence & D50F & D90M & Height & Branches & Pods & Seeds & TSW \\
\hline D50F & 0.17 & & & & & & & \\
D90M & -0.01 & 0.10 & & & & & & \\
Height & 0.17 & 0.09 & $-0.42^{*}$ & & & & & \\
Branches & 0.12 & -0.05 & -0.29 & $0.56^{* *}$ & & & & \\
Pods & 0.13 & 0.00 & $-0.39^{*}$ & $0.91^{* *}$ & $0.47^{* *}$ & & & \\
Seeds & 0.11 & 0.11 & -0.09 & $0.54^{* *}$ & 0.15 & $0.60^{* *}$ & & \\
TSW & -0.08 & -0.01 & -0.25 & $0.59^{* *}$ & 0.20 & $0.57^{* *}$ & 0.18 & $0.83^{* *}$ \\
GY & 0.05 & 0.02 & $-0.38^{*}$ & $0.86^{* *}$ & $0.38^{*}$ & $0.93^{* *}$ & $0.51^{* *}$ & 0.000 \\
\hline
\end{tabular}

Emergence, seedling emergence; D50F, days to $50 \%$ flowering; D90M, days to $90 \%$ maturity; Height, plant height; Branches, primary branches; Pods, pods per plant; Seeds, seeds per pod; TSW, thousandseed weight; GY, grain yield. * and ** indicate r values significant at $P \leq 0.05$ and $P \leq 0.01$, respectively $(\mathrm{n}=33)$

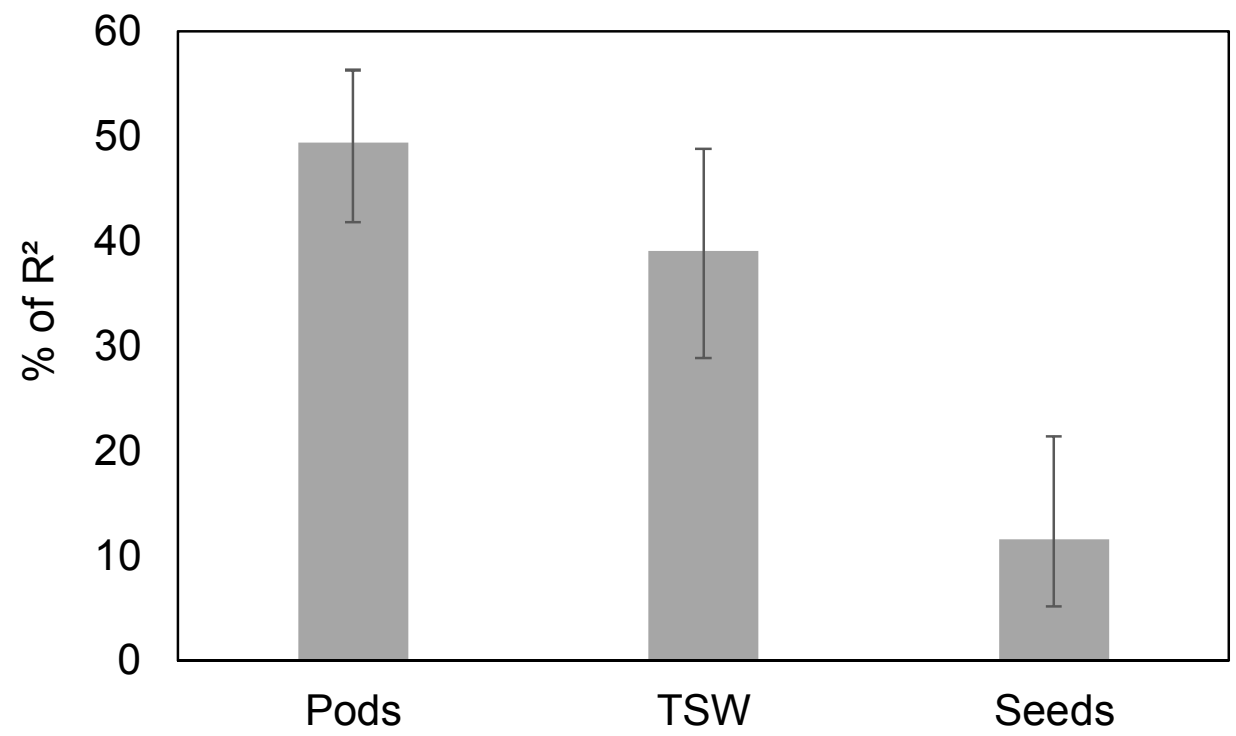

Figure 4. Relative importance of the three yield components on grain yield (LMG method). Total $R^{2}(99.1 \%)$ is normalized to sum 100\%. Bars indicate 95\% confidence intervals. Pods, pods per plant; TSW, thousand seed weight; Seeds, seeds per pod

\section{Discussion}

Increased interest in pulses is stemming research worldwide. New mash bean cultivars are being released to replace old genotypes in the quest for higher and more consistent yields in both traditional (Khaimichho et al., 2014; Sartaj and Anwar, 2015; Mbeyagala et al., 2016) and new cropping areas (Pekşen et al., 2015). The appraisal of yield related attributes and yield stability across environments is of crucial importance in development and introduction of improved varieties.

Several works addressed the genetic control of quantitative traits associated with yield in mash bean genotypes (Khaimichho et al., 2014; Hemavathy et al., 2015; Mbeyagala et al., 2016). Only in one work (Mbeyagala et al., 2016) this process involved a multilocation experiment as in our case. In the cited paper, a two-year test in six locations served to assess genotype yield and stability across environments, as well as each environment's discriminative ability and representativeness. In our case, the significant 
$\mathrm{G} \times \mathrm{E}$ interaction stimulated the assessment of genotype suitability for low vs. high yielding environments through Eberhart and Russel's (1966) approach: the wide range in average yield between Chakwal and Fateh Jang, on one side, and Piplan, on the other side (Table 2), facilitated the accomplishment of this task. Additional years are, nevertheless, needed to better state a location's characteristic or rate its value as testing environment, as also Mbeyagala et al. (2016) cautioned.

The procedure described allowed the eleven genotypes to be discriminated based on two equally important attributes as yield potential and stability. Five out of nine advanced breeding lines fell in the first quadrant (Figure 3), i.e. they expressed a competitive edge over the two commercial varieties (third quadrant), although at the expenses of stability. Another new line fell very close to the centre of the graph, indicating well balanced yield vs. stability. The remaining three new lines fell in the third quadrant, yet expressed some advantage over the two commercial varieties in either attribute. It results that the nine breeding lines possess in general ameliorated characteristics with respect to the two varieties they are intended to replace. However, no clear advantage in any morphological trait (Table 1) or yield component (Table 2) can be seen between the nine lines combined, on one side, and the two varieties combined, on the other side. It may be evinced, therefore, that the breeding programme targeted a general better efficiency in plant processes, more than a specific plant type associated with higher yield. It is noticed, incidentally, that the plant traits best related to yield in this experiment (Table 3) are almost the same evidenced in other works (Khaimichho et al., 2014; Hemavathy et al., 2015).

Lastly, mash bean is mostly grown in the sub-tropics during the summer, kharif (wet) season, although cultivation under winter, dry (rabi) conditions is also reported (Kumar and Kumar, 2016). Mash bean sensitivity to the drought (Baroowa et al., 2016) and especially heat stress (Kaur et al., 2015; Solai et al., 2015) is generally acknowledged. Flowering and the reproductive stage are indicated as the most critical period, during which time temperatures above $40^{\circ} \mathrm{C}$ adversely affect yield. In our experiment, this threshold was briefly passed after sowing only in the lowland environment (Piplan). This site also featured a sizeable water deficit (Figure 2) cumulating in the most sensitive reproductive stage (Baroowa et al., 2016). However, this circumstance did not hamper growth (Table 1) and the achievement of a high yield potential in this specific environment (Table 2). These points to factors other than water deficit as main drivers for mash bean yield in the three surveyed environments.

\section{Conclusions}

Eleven genotypes of mash bean comprising two commercial varieties and nine advanced breeding lines, tested in three environments in Punjab, Pakistan, have portrayed a remarkable variation in plant development and morphology, as well as grain yield and yield components. This provides enough scope for significant improvement of plant traits through selection.

Five new lines have exhibited higher yield potential under favourable conditions, reaching up to $1000 \mathrm{~kg} \mathrm{ha}^{-1}$ yield that is a level seldom echoed in the literature. Three other lines have shown a yield potential similar to that of commercial varieties, in exchange for which the new lines have featured a slightly higher yield stability. 
The present work demonstrates, in accordance with other literary sources, that there is ample space for improvement of the mash bean crop in view of a wider diffusion in the sub-tropical to temperate areas of the world.

The research on mash bean is committed to further breeding effort aimed at obtaining more genotypes, and multi-location testing in view of releasing new improved varieties.

Compliance with Ethical Standards. There is no potential conflict of interests and authors confirm that the field studies did not involve endangered or protected species.

\section{REFERENCES}

[1] Baroowa, B., Gogoi, N., Farooq, M. (2016): Changes in physiological, biochemical and antioxidant enzyme activities of green gram (Vigna radiata $\mathrm{L}$.) genotypes under drought. - Acta Physiologiae Plantarum 38(9): 219. https://doi.org/10.1007/s11738-016-2230-7.

[2] Blanche, S. B., Utomo, H. S., Wenefrida, I., Myers, G. O. (2009): Genotype×environment interactions of hybrid and varietal rice cultivars for grain yield and milling quality. - Crop Science 49(6): 2011-2018.

[3] Eberhart, S. A., Russel, W. A. (1966): Stability parameters for comparing varieties. - Crop Science 6: 36-40.

[4] Ghafoor, A., Ahmad, Z., Qayyum, A. (2003): Black gram (Vigna mungo L. Hepper) germplasm catalogue. - Plant Genetic Resources Programme, PARC/JICA, Islamabad, Pakistan, pp. 75-80.

[5] GOP (Government of Pakistan). (2017): Economic survey of Pakistan. - Economic Advisory Wing, Finance Division, Islamabad.

[6] Hargreaves, G. H., Samani, Z. A. (1985): Reference crop evapotranspiration from temperature. - Applied Engineering in Agriculture 1: 96-99.

[7] Hemavathy, A. T., Shunmugavalli, N., Anand, G. (2015): Genetic variability, correlation and path co-efficient studies on yield and its components in mungbean [Vigna radiata (L.) Wilczek]. - Legume Research 38(4): 442-446.

[8] Hill, J. (1975): Genotype $\times$ environment interactions: A challenge to plant breeding. Journal of Agricultural Science 85(3): 477-493.

[9] Kaur, R., Bains, T. S., Bindumadhava, H., Nayyar, H. (2015): Responses of mungbean (Vigna radiata L.) genotypes to heat stress: effects on reproductive biology, leaf function and yield traits. - Scientia Horticulturae 197: 527-541.

[10] Khaimichho, E. B., Hijam, L., Sarkar, K. K., Mukherjee, S. (2014): Genetic control and character association estimates of yield and yield attributing traits in some mungbean genotypes. - Journal of Crop and Weed 10(2): 82-88.

[11] Kumar, S. T., Kumar, P. A. (2016): Effect of tillage and nutrient-management practices on yield, economics and soil health in rice (Oryza sativa)-greengram (Vigna radiata) cropping system under rainfed condition of Odisha. - Indian Journal of Agronomy 61(2): 148-153.

[12] Lindeman, H. G., Merenda, P. E., Gold, R. Z. (1980): Introduction to bivariate and multivariate analysis. - Scott Foresman, Glenview, IL, USA.

[13] Mbeyagala, E. K., Amayo, R., Obuo, J. E. P. (2016): Adaptation of introduced mungbean genotypes in Uganda. - African Crop Science Journal 24(2): 155-166.

[14] Mohammad, W., Shehzadi, S., Shah, S. M., Shah, Z. (2010): Effect of tillage and crop residues management on mungbean (Vigna radiata (L.) Wilczek) crop yield, nitrogen fixation and water use efficiency in rain fed areas. - Pakistan Journal of Botany 42: 17811789.

[15] Pekşen, E., Toker, C., Ceylan, F. O., Farooq, T. A. M. (2015): Determination of promising high yielded mungbean (Vigna radiata (L.) Wilczek) genotypes under middle Black Sea Region of Turkey. - Anadolu Journal of Agricultural Sciences 30(2): 169-175. 
[16] RDCT (R Development Core Team). (2012): R: A language and environment for statistical computing. - R Foundation for Statistical Computing, Vienna. http://cran.r-project.org/.

[17] Sartaj, K., Anwar, M. T. (2015): Status of pulses in Pakistan. - RAP Publication (2015/05): 117-129.

[18] Sen, S. (1996): Economic Botany. - New Central Book Agency (Pvt.) Ltd. Calcutta, India, 42-43 pp.

[19] Sharma, P., Sekhon, H. S., Bains, T. S. (2012): Performance and growth analysis in Mash bean genotypes. - World Journal of Agricultural Sciences 8(3): 303-308.

[20] Sharma, A. (2014): Current trends in pulse crops production: an overview. - Economic Affairs 59: 569-578.

[21] Singh, G., Kumar, D., Sharma, P. (2015): Effect of organics, biofertilizers and crop residue application on soil microbial activity in rice-wheat and rice-wheat mungbean cropping systems in the Indo-Gangetic Plains. - Cogent Geoscience 1: 1085296. https://doi.org/10.1080/23312041.2015.1085296.

[22] Solai, M. A. P., Vijayalakshmi, C., Basu, P. S. (2015): Effect of high temperature on flowering pattern, pollen germination and pod setting in green gram (Vigna radiata (L.) Wilczek). - The International Journal of Plant Reproductive Biology 7(1): 59-66.

[23] Yan, W. K., Kang, M. S. (2003): GGE biplot analysis: A graphical tool for breeders, geneticists and agronomists. - Boca Raton, USA: CRC Press. 